Corrigendum

\title{
Corrigendum to "Quaternary glaciation and hydrologic variation in the South American tropics as reconstructed from the Lake Titicaca drilling project" [Quaternary Research 68 (2007) 410-420]
}

\author{
Sherilyn C. Fritz ${ }^{\mathrm{a}, \mathrm{b}, *}$, Paul A. Baker ${ }^{\mathrm{c}}$, Geoffrey O. Seltzer ${ }^{\mathrm{d}}$, Ashley Ballantyne ${ }^{\mathrm{c}}$, Pedro Tapia ${ }^{\mathrm{a}}$, \\ Hai Cheng ${ }^{\mathrm{e}}$, R. Lawrence Edwards ${ }^{\mathrm{e}}$ \\ ${ }^{\text {a }}$ Department of Geosciences, University of Nebraska, Lincoln, NE 68588-0340, USA \\ ${ }^{\mathrm{b}}$ School of Biological Sciences, University of Nebraska, Lincoln, NE 68588-0340, USA \\ ${ }^{\mathrm{c}}$ Division of Earth and Ocean Sciences and Nicholas School of the Environment and Earth Sciences, Duke University, Durham, NC 27708, USA \\ ${ }^{\mathrm{d}}$ Department of Earth Sciences, Syracuse University, Syracuse, NY 13244, USA \\ ${ }^{\mathrm{e}}$ Department of Geology and Geophysics, University of Minnesota, Minneapolis, MN 55455, USA
}

Available online 4 March 2008

On page 416, an incorrect version of Table 3 was inadvertently published. The corrected Table 3 is presented here.

Table 3

Equations used to calculate age (cal yr BP) for samples from LT01-2B

\begin{tabular}{|c|c|c|}
\hline Upper depth & Lower depth & Age-depth equation \\
\hline (mblf) & (mblf) & $x=$ depth (mblf) \\
\hline 0 & 4.34 & $4307 x+2540$ \\
\hline 4.34 & 15.74 & $615 x+18583$ \\
\hline 15.74 & 41.98 & $1410 x+6070$ \\
\hline 41.98 & 45.429 & $16602 x-631683$ \\
\hline 45.429 & 51.102 & $1023 x+76116$ \\
\hline 51.102 & 72.02 & $3529 x-51924$ \\
\hline 72.02 & 76.446 & $2275 x+38369$ \\
\hline 76.446 & 92.71 & $1571 x+92188$ \\
\hline 92.71 & 115.64 & $2884 x-29512$ \\
\hline 115.64 & 123.213 & $2579 x+5699$ \\
\hline 123.213 & 135.45 & $3766 x-140469$ \\
\hline
\end{tabular}

See text for further details.

DOI of original article: 10.1016/j.yqres.2007.07.008.

* Corresponding author. Department of Geosciences, University of Nebraska, Lincoln, NE 68588-0340, USA. Fax: +1 4024724917.

E-mail address: sfritz2@unl.edu (S.C. Fritz). 